\title{
Laryngopharyngeal reflux disease in a series of Sri Lankan patients
}

\author{
Kirihena K.D.R.A., Gunarathna C.K. \\ Lady Ridgway Hospital, Colombo.
}

\begin{abstract}
Introduction

Laryngopharyngeal reflux disease (LPR) occurs due to reflux of gastric contents into the larynx, pharynx and upper aerodigestivetractas a result of upper oesophageal sphincter dysfunction. Other aliases commonly used are extraesophageal reflux, reflux laryngitis or posterior laryngitis. LPR contributes up to $50 \%$ of laryngeal complaints hence; it is commonly encountered in clinical practice. LPR is present in $4-10 \%$ of those with gastro oesophageal reflux disease (GORD) while, about 20-70\% with LPR has symptoms of GORD. However, there is paucity of data regarding LPR, its characteristics and associations in a Sri Lankan population. Therefore, this study aimed to describe the demographic characteristics, presenting symptoms, dietary patterns and associations and laryngoscopic findings in the study population. It also explores the relationship between the reflux symptoms index (RSI) and the reflux findings score (RFS) and the effect of treatment on the above parameters.
\end{abstract}

Reflux symptom index (RSI)-(0-5), Max -45

1. Throat clearance

2. Hoarseness/problem with voice

3. Excessive throat mucus/post nasal drip

4. Difficulty in swallowing food, liquid

5. Coughing after eating or lying down

6. Breathing difficulties/chocking episodes

7. Troublesome/annoying cough

8. Sensation of lump in the throat

9. Heartburn/chest pain or acid coming up
Reflux finding score (0-26) on FOL

\begin{tabular}{|c|c|}
\hline Finding & Score \\
\hline Subglottic edema(pseudo sulcus vocalis) & $\begin{array}{l}0=\text { absent } \\
2=\text { present }\end{array}$ \\
\hline Ventricular obliteration & $\begin{array}{l}2=\text { partial } \\
4=\text { complete }\end{array}$ \\
\hline Erythema/hyperemia & $\begin{array}{l}2=\text { arytenoids only } \\
4=\text { diffuse }\end{array}$ \\
\hline Vocal cord edema & $\begin{array}{l}1=\text { mild } \\
2=\text { moderate } \\
3=\text { severe } \\
4=\text { polypoid }\end{array}$ \\
\hline Diffuse laryngeal edema & $\begin{array}{l}1=\text { mild } \\
2=\text { moderate } \\
3=\text { severe } \\
4=\text { obstructing }\end{array}$ \\
\hline Posterior commissure hypertrophy & $\begin{array}{l}1=\text { mild } \\
2=\text { moderate } \\
3=\text { severe } \\
4=\text { obstructing }\end{array}$ \\
\hline Granuloma/granulation & $\begin{array}{l}2=\text { present } \\
0=\text { absent }\end{array}$ \\
\hline Thick endolaryngeal mucus/other & $\begin{array}{l}2=\text { present } \\
0=\text { absent }\end{array}$ \\
\hline
\end{tabular}

Following dietary habits were considered and depending on the amount of consumption, Dietary Score was given for each (0-5) with the maximum of 60 points.(Chili, Curries, Tea, Coffee, Fatty foods, Onions, Sour fruits, Tomatoes, Vinegar, Pickles, Bread, Hoppers)

\section{Results}

65 patients were included. Of these 51 were female $(77.3 \%)$. The mean age was 41.1 (range 20-78, SD 13.1). The mean RSI and RFS were 9.2 (SD 2.9) and 6.9 (SD 2.5) respectively. Highest observed were troublesome coughs 
(0.25) and breathing difficulties (0.37). Highest observed RFS were erythema (2.03), ventricular obliteration (1.54) and posterior commissure hypertrophy (1.18) and lowest observed was vocal cord granuloma (0). $27.7 \%$ of patients had associated dental erosions and $12.3 \%$ had symptoms suggestive of sinusitis.

\section{Methodology}

Consecutive patients presented with the clinical diagnosis of LPR over one year period were included. Demographic, dietary and RSI data were obtained by mean of an interviewer administered questionnaire. FOL was performed in all patients by the same investigators. Patients were given uniform treatment with lifestyle modification and medication including antacids and proton pump inhibitors. Routine follow up and assessment with repeat administration of the questionnaire and FOL was arranged for all patients at a period of 4 weeks from the initial assessment.Reflux scores were sensation of lump in throat (2.0), throat clearance (1.6) and heartburn (1.9) while, lowest observed There was no association between the dietary score and the RSI ( $p=0.59)$ or RFS $(p=0.83)$. However, high dietary score was significantly associated with vocal fold edema $(p=0.45)$ and diffuse laryngeal edema $(p=0.49)$. There was no significant association between RFS $>7$ and the RSI ( $p=$ 0.531).

Statistically significant improvements in RSI ( $p$ $<0.001)$, RFS $(\mathrm{p}<0.001)$ and dietary score $(\mathrm{p}<$ $0.001)$ were seen at post intervention follow up.

Mean age was 41.1 years

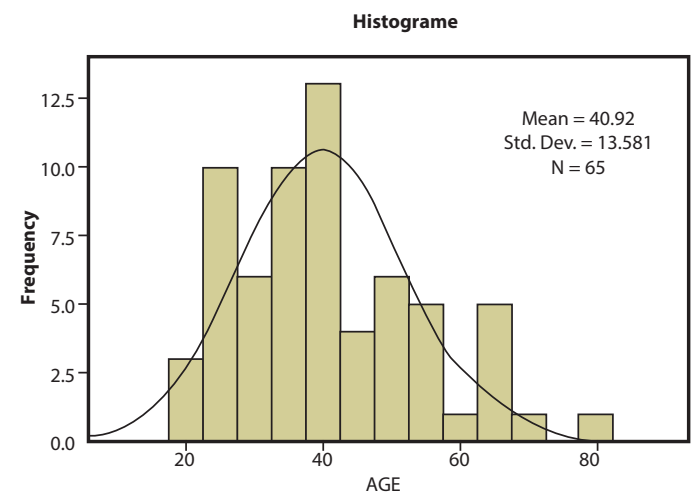

Figure 1- Age Distribution of the sample population.

Table 1- Reflux finding score

\begin{tabular}{|l|l|l|}
\hline Findings & $\begin{array}{l}\text { Mean } \\
\text { score }\end{array}$ & $\begin{array}{l}\text { Per- } \\
\text { centage } \\
\text { observed }\end{array}$ \\
\hline $\begin{array}{l}\text { 1 Subglottic edema(pseudo } \\
\text { sulcus vocalis) }\end{array}$ & 0.75 & 40.0 \\
\hline 2 Ventricular obliteration & $\mathbf{1 . 5 4}$ & $\mathbf{8 7 . 2}$ \\
\hline 3 Erythema/hyperemia & $\mathbf{2 . 0 3}$ & $\mathbf{9 8 . 5}$ \\
\hline 4 Vocal cord edema & 0.77 & 64.2 \\
\hline 5 Granuloma/granulation & 0.00 & 0.0 \\
\hline 6 Diffuse laryngeal edema & 0.09 & 4.6 \\
\hline $\begin{array}{l}\text { 7 Posterior commissure } \\
\text { hypertrophy }\end{array}$ & $\mathbf{1 . 1 8}$ & $\mathbf{6 6 . 2}$ \\
\hline $\begin{array}{l}\text { 8 Thick endolaryngeal } \\
\text { mucus/other }\end{array}$ & 0.62 & 56.9 \\
\hline
\end{tabular}

Table 2-Dietery Consumption Pattern in LPR patients

\begin{tabular}{|l|l|}
\hline Food item & $\begin{array}{l}\text { Mean consumption } \\
\text { score }\end{array}$ \\
\hline Chillie & 2.03 \\
\hline Curry & 1.89 \\
\hline Tea & 2.86 \\
\hline Coffee & 0.43 \\
\hline Fat & 1.62 \\
\hline Onion & 1.74 \\
\hline Sour food & 1.85 \\
\hline Tomato & 1.23 \\
\hline Vinegar & 0.34 \\
\hline Pickle & 0.26 \\
\hline Bread & 1.05 \\
\hline Hoppers & 0.49 \\
\hline
\end{tabular}


Kirihena K.D.R.A., Gunarathna C.K. Laryngopharyngeal reflux disease in a series of Sri Lankan patients Volume : 4; Issue1; pp 09 - 12

Table 3- Reflux Symptom Index

\begin{tabular}{|c|c|c|}
\hline Reflux symptom & $\begin{array}{l}\text { Mean } \\
\text { score }\end{array}$ & $\begin{array}{l}\text { Percentage } \\
\text { observed }\end{array}$ \\
\hline 1. Throat clearance & 1.85 & $72.5 \%$ \\
\hline 2. Hoarseness & 0.92 & $47.7 \%$ \\
\hline $\begin{array}{l}\text { 3. Excessive throat } \\
\text { mucus }\end{array}$ & 1.09 & $53.8 \%$ \\
\hline $\begin{array}{l}\text { 4. Difficult in swal- } \\
\text { lowing }\end{array}$ & 0.48 & $29.2 \%$ \\
\hline $\begin{array}{l}\text { 5. Coughing after } \\
\text { eating or lying } \\
\text { down }\end{array}$ & 0.45 & $29.2 \%$ \\
\hline $\begin{array}{l}\text { 6. Breathing diffi- } \\
\text { culties }\end{array}$ & 0.37 & $23.1 \%$ \\
\hline $\begin{array}{l}\text { 7. Troublesome } \\
\text { cough }\end{array}$ & 0.25 & $13.4 \%$ \\
\hline $\begin{array}{l}\text { 8. Sensation of } \\
\text { lump in the } \\
\text { throat }\end{array}$ & 2.06 & $84.6 \%$ \\
\hline 9. 9 Heartburn & 1.63 & $70.9 \%$ \\
\hline
\end{tabular}

Mean RSI score $=9.15 ; \mathrm{SD}=\mathbf{2 . 9 2}$

Table 4-Complications and Associations.

\begin{tabular}{|l|l|l|}
\hline Complication & $\begin{array}{l}\text { Fre- } \\
\text { quency }\end{array}$ & $\begin{array}{l}\text { Percent- } \\
\text { age }\end{array}$ \\
\hline Sinusitis & 8 & $12.3 \%$ \\
\hline $\begin{array}{l}\text { Otitis media with effu- } \\
\text { sion }\end{array}$ & 6 & $9.2 \%$ \\
\hline OSA & 6 & $9.1 \%$ \\
\hline Dental caries & 18 & $27.7 \%$ \\
\hline Bronchial asthma & 5 & $7.7 \%$ \\
\hline Bronchiectasis & 1 & 1.5 \\
\hline
\end{tabular}

Table 5- Pre and Post Treatment Reflux Symptom

\begin{tabular}{|l|l|l|}
\hline Reflux symptom & $\begin{array}{l}\text { Pre Treatment } \\
\text { Mean score }\end{array}$ & $\begin{array}{l}\text { Post Treat- } \\
\text { ment Mean } \\
\text { score }\end{array}$ \\
\hline 1 Throat clearance & 1.85 & .56 \\
\hline 2 Hoarseness & 0.92 & .32 \\
\hline $\begin{array}{l}\text { 3 Excessive throat } \\
\text { mucus }\end{array}$ & 1.09 & .43 \\
\hline $\begin{array}{l}\text { 4 Difficult of swal- } \\
\text { lowing }\end{array}$ & 0.48 & .12 \\
\hline $\begin{array}{l}\text { 5 Coughing after } \\
\text { eating or lying } \\
\text { down }\end{array}$ & 0.45 & .11 \\
\hline $\begin{array}{l}\text { 6 Breathing diffi- } \\
\text { culties }\end{array}$ & 0.37 & .20 \\
\hline $\begin{array}{l}\text { 7 Troublesome } \\
\text { cough }\end{array}$ & 0.25 & .02 \\
\hline $\begin{array}{l}\text { 8 Sensation of } \\
\text { lump in the throat }\end{array}$ & 2.06 & .23 \\
\hline 9 Heartburn & 1.63 & .34 \\
\hline
\end{tabular}

Figure 2 - Mucosal erythema and granuloma formation

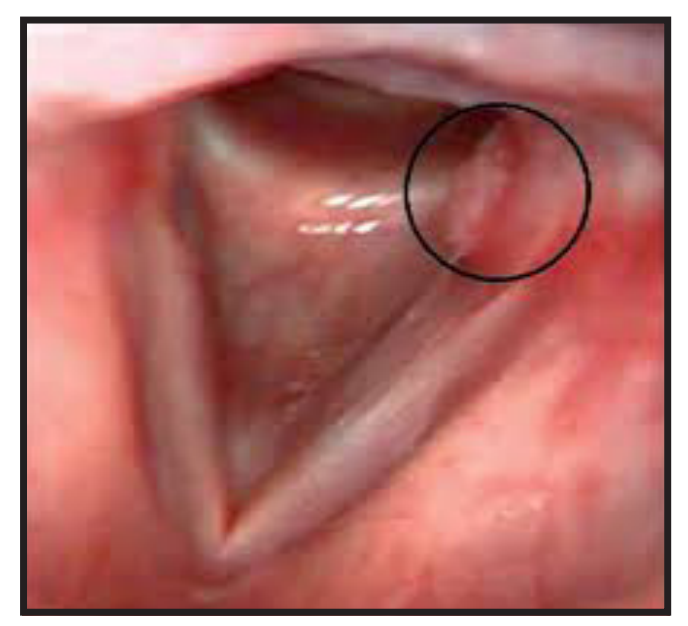

Figure 3-Thick mucosal strings

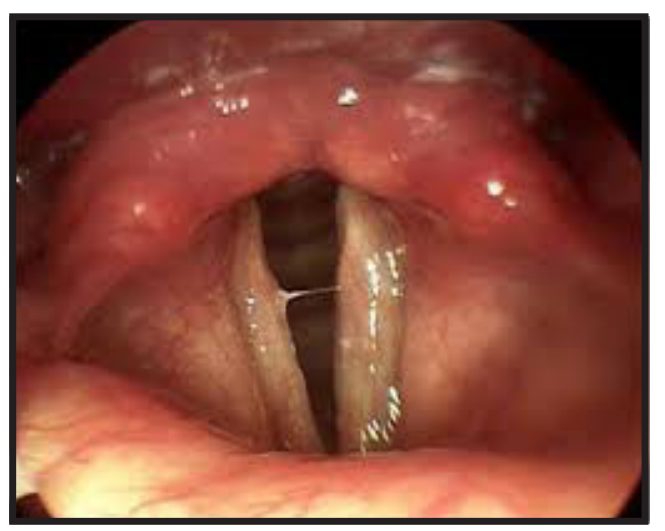




\section{Discussion}

Efficacy of anti-reflux medical treatment is highly variable in the literature. In prospective studies withplacebo control, anti-reflux medication showed marked improvement in reflux symptoms and signs $[1,2]$ while it failed to demonstrate significantly greater improvement in other studies when compared to placebo [3, 4]. However, in so many studies without placebo control, anti-reflux medication was found to be effective in resolution of laryngeal symptoms and signs. The efficacy was reported to be around $65 \%$ [6-5]. The controversial results of these studies may be due to differences in inclusion criteria, assessment of the severity and outcome of symptoms and signs, and different doses or duration of the medication.

In this study, empiric anti-reflux treatment with duration of 4 weeks yielded statistically significantly improvement in RSI and RFS. Relating with the symptoms; treatment was successful in all subtopics of RSI regarding the severity but not successful for complete eradication of symptoms as assessed in terms of frequency. This means that the treatment had decreased the severity of the symptoms significantly in all subtopics but could not eradicate the complaints totally in a significant number of the patients in the study group.

\section{Conclusions}

LPR in the study population was more common in females. The mean RSI and RFS are lower than that observed in previous studies. Lack of association between RSI and RFR is noteworthy. Dietary modifications and pharmacological management are associated with statistically significant RSI and RFS improvement.

\section{References}

1. El-Serag HB, Lee $\mathrm{P}$, Buchner A, Inadomi JM, Gavin M, McCarthy DM. Lansoprazole treatment of patients with chronic idiopathic laryngitis: a placebocontrolled trial. Am J Gastroenterol 2001; 96:979-83.

2. Eherer AJ, Habermann W, Hammer HF, Kiesler K, Friedrich G, Krejs GJ. Effect of pantoprazole on the course of reflux-associated laryngitis: a placebocontrolled double-blind crossover study. Scand J Gastroenterol 2003; 38:462-7.

3. Steward DL, Wilson KM, Kelly DH, Patil MS, Schwartzbauer HR, Long JD, et al. Proton pump inhibitor therapy for chronic laryngopharyngitis: a randomized placebo-control trial. Otolaryngol Head Neck Surg 2004; 131:342-50.

4. Vaezi M, Richter J, Stasney SR, Spiegel JR, Iannuzzi RA, Crawley JA, et al. Treatment of chronic posterior laryngitis with esomeprazole. Laryngoscope 2006; 116:254-60.

5. Kamel PL, Hanson D, Kahrilas PJ. Omeprazole for the treatment of posterior laryngitis. Am J Med 1994; 96:321-6.

6. DelGaudio JM, Waring JP. Empiric esomeprazole in the treatment of laryngopharyngeal reflux. Laryngoscope 2003; 113:598-601.

Corresponding Author:

Dr.K.D.R.A.Kirihena,

Consultant ENT Surgeon,

Lady Ridgeway Hospital

Colombo.

E-mail:kirihene@hotmail.com 